bogs were being laid down, its existence as an indigenous tree during the last thousand years is extremely doubtful.

\section{International Federation of Eugenic Organizations}

We have received a copy of the report of the ninth Conference of the International Federation of Eugenic Organizations, edited by the honorary administrative secretary, Mrs. C. B. S. Hodson, and published at 406 Fulham Road, London. The Conference met on Sept. 11-15, 1930, at Farnham, Dorset, and Larmer Tree Grounds, Tollard Royal, Wilts. Associated public meetings were held at the Tithe Barn, Hinton St. Mary, Dorset, at the invitation of Capt. Pitt-Rivers. The first conference, under the chairmanship of Sir Arthur Keith, considered the standardisation of human measurements, with opening papers by Miss M. L. Tildesley on the physical and Miss B. Schieffelin on the mental side. A conference on race crossing, with Dr. Alfred Ploetz in the chair, received contributions from Dr. Mjöen, Prof. C. G. Seligman, Dr. van Herwerden, Prof. Ruggles Gates, Dr. C. B. Davenport, and Prof. Eugen Fischer. At another session international programmes for research in racial psychiatry were presented by Prof. Rüdin, and in racial psychology by Prof. Seligman. An afternoon was devoted to heredity in man, with Prof. Gates in the chair, and contributions by Dr. P. J. Waardenburg, Dr. C. J. Bond, Dr. G. P. Frets, and Dr. Heuyer. The report includes a summary of the discussion on each paper. The last part is devoted to general reports, including a brief statement from twelve countries regarding work on the eugenic or dysgenic effects of the War, and statements concerning recent eugenic work in Czechoslovakia, Finland, South Africa, Holland, Germany, and Austria. Dr. H. H. Laughlin contributes a survey of eugenical work in the United States, Dr. Mjöen one for Norway, and Dr. Schrieber for France. This pamphlet of a hundred pages is a useful summary of work having anthropological and medical as well as eugenical aspects.

\section{Wood Decay in Motor-Cars in the Tropics}

THE practical importanee of this question is indicated in a brief note in the Philippine Journal of Science (vol. 46, No. 2) by C. J. Humphrey, mycologist to the Bureau of Science, Manila. He states that the depreciation of imported automobiles in the tropics from this cause reaches "a staggering figure in proportion to the investment". Most of the cars in the Philippines are American, a few come from Europe; in either case the woods used in their construction are almost exclusively temperate zone species, selected for other properties than their durability. The decay sets in as the result of moisture in the wood, but, under the conditions in the tropics in the rainy season, water almost inevitably penetrates and, in the humid atmosphere, does not easily dry out again. The author states that "six months under test conditions very highly favourable for decay will destroy for all practical use nearly all the temperate zone woods now used in American or Europeanmade cars ". Up to the present three species of the higher fungi have been observed fruiting on the rotting wood taken from cars; many more species probably contribute, but most of them are Hymenomycetes. The remedies for the trouble seem clear : either the use of the heartwood of durable species of timber, presumably tropical species, by the manufacturer, or else the non-durable timbers must be adequately treated with a preservative.

\section{Light upon Eggs}

ANALYsis shows that an inverse relation exists between the amount of daylight and the price of hens' eggs in successive months of the year. That in turn is correlated with the amount of food a hen may eat per day, so that the more light, the more food, and, other things being equal, the more eggs. Artificial lighting has been used on a large scale in the United States to shorten the long nights and induce hens to lay more, but it cannot be said to be a common practice in Britain. The results obtained by J. W. Rhys and Raymond T. Parkhurst at the National Institute of Poultry Husbandry suggest, however, that its use might well be extended (Bull. No. 6). During the winter months the 120 pullets under lights laid 950 more eggs than an equal number without lights. For the 48 weeks of the test the lighted pen yielded 1086 eggs more than the unlighted pen. The lighted pullets laid an average of 173.5 eggs and the unlighted $16 \mathrm{I} \cdot 0$ eggs. Financially, the "morning and evening lights' pen was most successful, the margin of profit over food and lighting costs being 11.58 pence a dozen eggs. Hens apparently give the best results under a 14-hour day.

\section{The First 'Sky-scraper'}

A PoINT of considerable interest in the history of architecture has just been settled by a joint committee of the American Institute of Architects and the Illinois Society of Architects, which, having watched the demolition of the Home Insurance Building in Chicago, has declared it to be "the first tall structure of metal construction". The essential feature of a 'sky-scraper' is the metal skeleton, defined as "a type of construction in which a metal frame or cage, composed of girders, beams, and columns, supports all internal and external loads and carries all stresses to the foundations ". Claims had been set up that the Tacoma Building of 1888 was the first tall metal skeleton building, but the committee states that in the Home Insurance Building there was "a complete skeleton framework, floor loads were carried by both interior and exterior columns, wall loads were transferred to columns, and columns were supported on independent footings ". The Home Insurance Building was designed by William Le Baron Jenney and was erected in 1885 . It has now been removed to make room for the gigantie Field Building in which 25,000 tons of steel will be used, but it will henceforth have its place in history as the first 'skyscraper'.

\section{Economic Uses of Beryllium}

Amonc the rarer metals which are light in weight and therefore suggest themselves for employment in the aircraft and automobile industries, beryllium

No. 3255, VoL. 129] 
stands out prominently. It is lighter than aluminium and has a much higher melting point than either aluminium or magnesium. In order to provide authoritative information about beryllium and the distribution of deposits of beryl-the only source of which adequate supplies are available-a useful little monograph has been prepared by the Mineral Resources Department of the Imperial Institute ("The Mineral Industry of the British Empire and Foreign Countries-Beryllium (Glucinum) and Beryl ", 1931, pp. 26, price 6d.). At present the metal is being produced commercially only in Germany and the United States. However, it is clear from the details provided that the British Empire is in a strong position to exploit its resources of beryl if adequate financial help can be found to follow up the preliminary work already accomplished in the field and laboratory. As is usual in this well-known series of monographs on economic minerals, there is a very full bibliography of the leading literature on the subjects dealt with.

\section{National Institute of Industrial Psychology}

THE eleventh annual report and the accounts for the year 1931 of the National Institute of Industrial Psychology have recently been published. Thedevelopment of the Institute's work, in spite of the present financial crisis, continues satisfactorily. There is reported an increase of more than twenty-six per cent in the number of industrial and commercial firms for which the Institute has carried out investigations during the year, and an increase of nearly seventeen per cent in the number of cases examined for vocational guidance. The investigations are concerned with very varied activities, including work in gold mines, gasworks, a fish paste factory, and schools, and the problems investigated include equipment and lay-out of factories, as well as bonus schemes and staff selection. The very valuable work on vocational guidance continues, and while the Institute has acquired knowledge which enables it to advise young people on the choice of a career, yet it is recognised that much remains to be done: research work which will require several years for fruition is in progress. An allied problem, namely, occupational analysis, is also being continued, and studies being made of the abilities required for the various types of women's secretarial work and nursing. Other researches described include the nature and measurement of the mental abilities involved in factory assembly operations, motor drivers' tests, colour discrimination, and a very important investigation into the part played by rhythm in typewriting.

\section{Health of the Army}

THE health of the Army, at home and abroad, during 1930 is dealt with in the War Office Report recently issued (H.M. Stationery Office. $2 s .6 d$. net) The ratio per 1000 of the strength of men admitted to hospital was $428 \cdot 4$, which is the lowest since the War, with the exception of 1928 . Malaria caused 7365 admissions, venereal diseases, 6146, and inflammation of the tonsils, 5519. The principal causes of invaliding from the Army were tuberculosis, 200 cases, and middle ear disease, 182 cases. Enteric fevers accounted for only 253 cases, of which 207 were in India. A single case of undulant fever is reported, an abortus infection at York. There were 534 cases of pneumonia, with a case mortality of $10 \cdot 6$ per cent. It is of interest that the pneumonia figures of forty years ago, selected at random, give a mortality figure of 12 per cent. Considering the less efficient nursing then available, this suggests that effective treatment of pneumonia has not materially advanced. Some details are given of researches carried out by officers of the Royal Army Medical Corps.

\section{International Oceanography}

PRoF. R. DE BuEN, with the co-bperation of leading international oceanographers, has compiled a valuable chronological list of voyages, long and short, made by vessels of all countries that have resulted in addition to oceanographical knowledge ("Lista cronológica de las campañas y navegaciones a las que se deben observaciones científicas de caracter oceanográfico ". Memorias del Consejo Oceanográfico Ibero-Americano, No. 5, Madrid, 1930). The entries are arranged separately for each country, and indications are in most cases given of objects or results of the voyages, names of the leaders, and in some cases of scientific personnel. The compiler is open to receive corrections or additions to the list, which indeed appears to be very complete already. The earlier entries, which begin at the end of the fifteenth century, are for voy. ages primarily of a geographical nature. It is interesting to note that the British records, although not given in great detail, occupy nearly one-half the whole.

\section{Agricultural History}

THE Agricultural History Society of America wishes to secure as full bibliographical information as possible relating to books or essays on agricultural history for inclusion in its quarterly journal. Writers in the British Isles of essays on farming history and the history of rural life in all its phases, are therefore requested to forward details of their publications from time to time to the Associate Editor for Great Britain, Mr. G. E. Fussell, at 47 Maple Street, London, W.1. Information regarding sections of scientific works which contain historical data, works of general history, or the history of specific trades or districts which contain sections dealing with agricultural history, might also be included. The quarterly journal of the Society, Agricultural History, is obtainable on payment of an annual subscription of three dollars, which should be forwarded to the Treasurer, Agricul. tural History Society, Room 304, 1358 B Street S.W., Washington, D.C., U.S.A.

\section{The Remsen Memorial Collection}

Former students in chemistry at Johns Hopkins University have organised the chemistry alumni of the University, with Dr. Harry N. Holmes, of Oberlin Colleg'e, as president, and Dr. Lyman C. Newell, of Boston University, as secretary. Two meetings are held each year, ordinarily at the time of the meetings

No. 3255 , VoL. 129] 